\title{
Hastanede Yatırılarak İzlenen COVID-19 Hastalarının Klinik ve Laboratuvar Özellikleri ve Hastalık Ciddiyetini Belirleyen Faktörlerin Deg̃erlendirilmesi
}

\section{Evaluation of the Clinical and Laboratory Characteristics and Factors Determining the Severity of the Disease in Hospitalized COVID-19 Patients}

\author{
Duru MISTANOG̃LU ÖZATAG̃̄ (IID), PInar KORKMAZ1 (IID), Halil ASLAN² (IDD), Duygu PERÇIN³ (IID)
}

\footnotetext{
${ }^{1}$ Kütahya Sag̃ıı Bilimleri Üniversitesi Tıp Fakültesi, İnfeksiyon Hastalıkları Anabilim Dalı, Kütahya, Türkiye

${ }^{2}$ Kütahya Sag̃lık Bilimleri Üniversitesi Evliya Çelebi Eg̃itim ve Araștırma Hastanesi, Gastroenteroloji Anabilim Dalı, Kütahya, Türkiye

${ }^{3}$ Kütahya Sag̃lık Bilimleri Üniversitesi Tıp Fakültesi, Mikrobiyoloji ve Klinik Mikrobiyoloji Anabilim Dalı, Kütahya, Türkiye
}

Makale atıfı: Mıstanoğlu Özatağ D, Korkmaz P, Aslan H, Perçin D. Hastanede yatırılarak izlenen COVID-19 hastalarının klinik ve laboratuvar özellikleri ve hastalık ciddiyetini belirleyen faktörlerin değerlendirilmesi. FLORA 2021;26(4):646-54.

\section{ÖZ}

Giriş: SARS-COV-2 infeksiyonunda yüksek riskli hastaların tanımlanması ve ivedilikle tedaviye başlanması mortalite hızını azaltmak için gereklidir. Biz de çalışmamızda hastanemizde yatırılarak izlenen COVID-19 tanılı hastalarda klinik ve laboratuvar karakteristiklerin ve hastalık ciddiyetini belirleyen faktörlerin değerlendirilmesini amaçladık.

Materyal ve Metod: 15 Mart-1 Kasım 2020 tarihleri arasında hastanemiz Infeksiyon Hastalıkları Kliniği tarafından izlenen 18 yaş üzeri kesin/olası COVID-19 hastalarına ait dosyalar retrospektif olarak değerlendirildi.

Bulgular: Çalışmaya toplam 302 hasta dahil edilmiştir, hastaların \%50.3’ü erkektir. Çalışmaya katılan hastaların yaş ortalaması $62.11 \pm$ 17.15 yıldır. Hastaların \%51.3'ü 65 yaş ve üzerindedir. Hastalarımızda en sık eşlik eden hastalık hipertansiyon ve diyabetes mellitustur. Hastaların \%22.5'inde lenfosit sayısı 800'ün altında idi. Hastaların \%88.7'sinde toraks BT'de tutulum saptandı, bunların \%95.8'inde buzlu cam izlendi. Hastalarda en sık kullanılan antiviral tedavi favipiravir idi (\%59.6). Tüm hastaların \%25.8'inde ciddi hastalık mevcuttu. Yaşlı ve komorbiditesi fazla olan hastalarda COVID-19'un daha ciddi seyrettiği, bu hastalarda lenfopeni, hipofibrinojenemi ve hipoproteineminin daha fazla görüldüğü, AST, D-dimer, ferritin, LDH, CRP, prokalsitonin, troponin, PTZ ve INR değerlerinde hastalığın ciddiyetiyle ilişkili olarak anlamlı bir yükseklik olduğu tespit edilmiştir. Toraks BT'de konsolidasyon, infiltrasyon ve atelektazi, ciddi hastalığı olanlarda anlamlı olarak daha fazladır. Hastaların hastanede yatış süreleri ortalama $10.06 \pm 6.07$ gündür, yoğun bakım ünitesinde izlenme oranı \%12.6 olup, hastaların \%5'inde ölüm gerçekleşmiştir.

Sonuç: Ciddi COVID-19 için demografik, klinik ve laboratuvar prognostik faktörlerin iyi tanımlanması, hastalığın takip ve tedavi sürecinde hekimlere katkı sağlayabilecektir.

Anahtar Kelimeler: COVID-19; Laboratuvar bulgular; Klinik özellikler; Tedavi 


\title{
ABSTRACT \\ Evaluation of the Clinical and Laboratory Characteristics and Factors Determining the Severity of the Disease in Hospitalized COVID-19 Patients
}

\author{
Duru MISTANOG̃LU ÖZATAG̃'1, Pınar KORKMAZ1', Halil ASLAN², Duygu PERÇIN³
}

\footnotetext{
${ }^{1}$ Department of Infectious Diseases, Kütahya Health Sciences University Faculty of Medicine, Kütahya, Turkey

${ }^{2}$ Department of Gastroenterology, Kütahya Health Sciences University Evliya Çelebi Training and Research Hospital, Kütahya, Turkey

${ }^{3}$ Department of Microbiology and Clinical Microbiology, Kütahya Health Sciences University Faculty of Medicine, Kütahya, Turkey
}

Introduction: Identification of high-risk patients in SARS-COV-2 infection and prompt initiation of treatment are essential to reduce mortality rate. In our study, it was aimed to evaluate the clinical and laboratory characteristics of patients with a diagnosis of COVID19 who were hospitalized in our hospital and the factors that determine the severity of the disease.

Materials and Methods: The files of definite/probable COVID-19 patients over the age of 18 who were followed by the Infectious Diseases Clinic of our hospital between March 15 and November 1, 2020 were evaluated retrospectively.

Results: A total of 302 patients were included in the study, 50.3\% of the patients were males. Mean age of the patients participating in the study was $62.11 \pm 17.15$ years. $51.3 \%$ of the patients are 65 years or older. The most common comorbidities in our patients were hypertension and diabetes mellitus. It was determined that lymphocyte count was below 800 in $22.5 \%$ of the patients. Involvement was detected on thorax CT in $88.7 \%$ of the patients, ground glass was observed in $95.8 \%$. The most commonly used antiviral treatment in patients was favipiravir with $59.6 \%$. Severe disease was present in $25.8 \%$ of all patients. In elderly patients with high comorbidities, COVID-19 was more severe, lymphopenia, hypofibrinogenemia and hypoproteinemia were more common in these patients, and there were significant differences in AST, D-dimer, ferritin, $L D H, C R P$, procalcitonin, troponin, PTZ and INR values in relation to the severity of the disease. Consolidation, infiltration and atelectasis in thorax CT were significantly higher in patients with severe disease. The average hospitalization period of the patients was $10.06 \pm 6.07$ days, the rate of follow-up in the intensive care unit was $12.6 \%$, and $5 \%$ of the patients died.

Conclusion: Good identification of demographic, clinical and laboratory prognostic factors for severe COVID-19 may contribute to physicians in the follow-up and treatment of the disease.

Key Words: COVID-19; Laboratory findings; Clinical features; Treatment

\section{GíRiș}

Coronavirüsler tek zincirli, pozitif polariteli zarflı RNA virüsleridir. Soğuk algınlığı gibi kendini sınırlayan hafif infeksiyon tablolarının yanı sıra siddetli akut solunum sendromu coronavirus 1 (SARSCOV-1) infeksiyonu ve Orta Doğu solunum sendromu (MERS) infeksiyonu gibi daha ciddi solunum yolu infeksiyonlarına da yol açabilirler ${ }^{[1,2]}$. Aralık 2019'da Cin'in Wuhan kentinin merkez olduğu etyolojisi bilinmeyen pnömoni vakaları bildirilmis, 7 Ocak 2020'de hastallk etkeni yeni bir coronavirus olarak tanımlanmıstır, bu yeni coronavirusa Dünya Sağlık Örgütü (DSÖ) tarafından SARS-COV-2, yol açtığı hastalığa ise coronavirus hastalığı 2019 (COVID-19) adı verilmiștir ${ }^{[3,4]}$. Hastalık hızla ilk görülduuğü ülke olan olan Cin'den diğer ülkelere yayılmıs ve 11 Mart 2020 tarihinde DSÖ tarafından pandemi olarak ilan edilmiștir. Ülkemizde ilk vaka 11 Mart 2020 tarihinde saptanmıștır ${ }^{[5]}$.
COVID-19 dünya çapında endișe verici bir sağlik sorunudur. SARS-COV-2 infeksiyonu asemptomatik hastalık, ciddi vakalarda pnömoni, ağır akut solunum yolu infeksiyonu, böbrek yetmezliği ve ölümle seyredebilmektedir ${ }^{[2,5]}$. Hastalığın kesin bir antiviral tedavisi olmaması nedeniyle destek tedavi semptomların iyilestirilmesinde ve organ fonksiyonlarının korunmasında önemli bir yer tutmaktadır. Yüksek riskli hastaların tanımlanması ve ivedilikle tedaviye bașlanması mortalite hızını azaltmak için gereklidir ${ }^{[1]}$. COVID-19 klinik karakteristiklerinin anlașılması, yüksek riskli hastaların belirlenmesine ve hastalığın gelecekteki yönetimine katkı sağlayacaktır ${ }^{[6]}$. Bu nedenle biz de calıșmamizda hastanemizde yatırlarak izlenen COVID-19 tanılı hastaların klinik ve laboratuvar karakteristiklerinin ve hastalı ciddiyetini belirleyen faktörlerin değerlendirilmesini amaçladık. 


\section{MATERYAL ve METOD}

15 Mart-1 Kasım 2020 tarihleri arasında hastanemiz İnfeksiyon Hastalıkları Kliniği tarafından izlenen 18 yas üzeri kesin/olası COVID-19 hastalarına ait dosyalar retrospektif olarak değerlendirildi. Demografik, klinik, laboratuvar ve klinik gidiș ile ilgili bilgiler değerlendirildi. Olgu tanımları Sağlık Bakanlığı COVID-19 rehberine göre yapıldı. SARS-COV-2 Real Time Polimeraz Zincir Reaksiyonu (RT-PCR) testi negatif olmakla birlikte uygun klinik sikayetleri olan ve toraks bilgisayarlı tomografisi (BT)'nde viral pnömoni ile uyumlu bulguları olanlar olası olgu olarak kabul edildi. Olası vaka tanımına uyan olgulardan moleküler yöntemlerle SARS-CoV-2 saptanan olgular kesin vaka olarak tanımland. SARS-COV-2 RT-PCR testi negatif olmasına rağmen COVID-19 ile uyumlu klinik, laboratuvar ve radyolojik bulguları olan hastalarda 24 saat sonra tekrar RT-PCR testi yapildı ${ }^{[5]}$.

Hastalar klinik olarak Sağlık Bakanlığı COVID-19 Rehberi'ne göre komplike olmayan, hafif/ orta veya ciddi olarak siniflandirıld. Komplike olmamıs hastalık: Ates, kas/eklem ağrıları, öksürük ve boğaz ağrısı gibi bulguları olup solunum sıkıntısı olmayan (dakika solunum sayısı \%93 oda havasında) ve akciğer filmi ve/veya toraks BT'nin normal olması, hafif-orta seyirli pnömoni: Ates, kas/eklem ağrıları, öksürük ve boğaz ağrısı gibi bulguları olup, solunum sayısı $<30 /$ dakika olan, oda havasında $\mathrm{SpO}_{2}$ düzeyi $>\% 90$ üzerinde olan, ve akciğer grafisinde veya toraks BT'de hafif-orta pnömoni bulgusu olması, ağır pnömoni: Bilinç değișikliği, solunum sıkıntısı olanlar, solunum dakika sayısı $\geq 30$, oda havasında $\mathrm{SpO}_{2} \leq \% 90$, akciğer görüntülemesinde bilateral yaygin $(>\% 50)$ tutulu$\mathrm{mu}$ olması olarak tanımlandı. Hastaların hastanede izlem endikasyonu ve antiviral tedavi secimi, dozları Sağlık Bakanlığı COVID-19 Erișkin Hasta Tedavisi Rehberi önerileri doğrultusunda yapıld ${ }^{[7]}$. Oral alım yetersiz ise intravenöz sıv1 resüsitasyonu yapıldı. Hipoksik hastalara, \%93 hedef $\mathrm{O}_{2}$ satürasyonu ile 3-5 1/dakika nazal oksijen verildi. Oksijen ihtiyacı olan hastalara Ekim 2020 Sağlık Bakanlığı Rehberi güncellemesi sonrasında $6 \mathrm{mg} /$ gün deksametazon (veya eșdeğeri glukokortikoidler) maksimum 10 gün kullanıldı ${ }^{[7]}$. Tedaviye rağmen >30/dakika solunum hizı, dispne ilerlemesi olan ve oda havasinda $\mathrm{SpO}_{2}<\% 90$ olan hastalar yoğun bakım ünitesine (YBU்) devredildi. Hastaların hastanede yatıs süresi, yoğun bakımda izlem, ölüm, taburcu durumları kayıt edildi.

\section{Laboratuvar Ölçïmleri}

Hastalarda kesin tanı RT-PCR ile orofarengeal ve nasofarengeal swablarda SARS-COV-2 virusunun saptanması ile yapild. Hastalarda tam kan sayımı, elektrolitler, böbrek ve karaciğer testleri, kreatin kinaz ve $\mathrm{MB}$ fraksiyonu, high-sensitive troponin, D-dimer, ferritin, C-reaktif-protein (CRP) ve prokalsitonin calıșld. Gebe hastalar haric tüm hastalara toraks BT istendi. Calıșma için T.C Sağlık Bakanlığı'ndan gerekli izin ve lokal etik kurul onayı alındı. İstatistiksel analizler için NCSS (Number Cruncher Statistical System) programı kullanıldı. Calıșma verileri değerlendirilirken tanımlayıcı istatistiksel metodlar (ortalama, standart sapma, medyan, frekans, yüzde, minimum, maksimum) kullanıldı. Nicel verilerin normal dağılıma uygunlukları Shapiro-Wilk testi ve grafiksel incelemeler ile sınanmısttır. Normal dağılım gösteren nicel değișkenlerin ikiden fazla grup arası karș1laștırmalarında Tek yönlü varyans analizi ve Bonferroni düzeltmeli ikili değerlendirmeler kullanıldı. Normal dağılım göstermeyen nicel değiskenlerin ikiden fazla grup arası karșlaștırmalarında Kruskal-Wallis test ve Dunn-Bonferroni test kullanild. Nitel verilerin karșlaștırılmasında Pearson ki-kare test, Fisher-Freeman-Halton test kullanıld. İstatistiksel anlamllik $p<0.05$ olarak kabul edildi.

\section{BULGULAR}

Calıșmaya toplam 302 hasta dahil edilmiștir, hastaların \%50.3'ü $(n=152)$ erkektir. Calıșmaya katılan hastaların yas ortalaması $62.11 \pm 17.15$ (20-94) yıldır. Hastaların \%51.3'ü $(n=155) 65$ yas ve üzerindedir. Hastalarımı da en sk eșlik eden hastallk hipertansiyon ve diyabetes mellitus olup, tüm hastaların \%3'ünde $(\mathrm{n}=9)$ tanı anında gebelik mevcuttu. Hastalara ait karakteristik özelikler Tablo 1'de verilmiștir. Hastaların laboratuvar değerleri incelendiğinde, \%22.5'inde lenfosit say1sının 800'ün altında olduğu, \%11.6'sında trombosit sayısı 150 'in altında olduğu, \%43.4'ünde D dimer değerinin 1000'in üzerinde olduğu tespit edilmiștir. Hastalara ait laboratuvar değerleri Tablo 2 'de verilmiștir. 
Tablo 1. COVID-19 tanılı hastalarımızın karakteristikleri

\begin{tabular}{|c|c|c|c|c|}
\hline Karakteristik & $\begin{array}{l}\text { Tüm hastalar } \\
(302) \mathrm{n}(\%)\end{array}$ & $\begin{array}{c}\text { Komplike olmayan } \\
(43) \mathrm{n}(\%)\end{array}$ & $\begin{array}{l}\text { Hafif-ortapnömoni } \\
(181) \mathrm{n}(\%)\end{array}$ & $\begin{array}{l}\text { Ciddi pnömoni } \\
\text { (78) n (\%) }\end{array}$ \\
\hline Yaş (yıl) Ort \pm Ss medyan & $62.11 \pm 17.15(65)$ & $45.37 \pm 18.96(40)$ & $62.01 \pm 15.88(64)$ & $71.58 \pm 10.82(72)$ \\
\hline Cinsiyet (Erkek) & $152(50.3)$ & $26(60.4)$ & $86(47.5)$ & $40(51.2)$ \\
\hline Diyabetes mellitus & $82(27.2)$ & $2(4.6)$ & $52(28.7)$ & $28(35.9)$ \\
\hline Hipertansiyon & $115(38.1)$ & $5(11.6)$ & $68(37.5)$ & $42(53.8)$ \\
\hline Kardiyovaskuler hastalık & $37(12.3)$ & $3(6.9)$ & $20(11)$ & $14(17.9)$ \\
\hline Kronik obstruktif hastalık & $38(12.6)$ & $3(67.9)$ & $21(11.6)$ & $14(17.9)$ \\
\hline Malignite & $17(5.6)$ & $1(2.3)$ & $11(6)$ & $5(6.4)$ \\
\hline Kronik böbrek hastalığı & $21(7)$ & $0(0)$ & $13(7.1)$ & $8(10.2)$ \\
\hline Serebrovaskuler hastalık & $15(5)$ & $0(0)$ & $7(3.8)$ & $8(10.2)$ \\
\hline Komorbidite sayı $\geq 2$ & $92(30.5)$ & $4(9.3)$ & $52(28.7)$ & $52(66.7)$ \\
\hline Pcr pozitif & $273(90.4)$ & $43(100)$ & $156(86.1)$ & $74(95)$ \\
\hline Gebe & $9(3)$ & $6(13.9)$ & $3(1.6)$ & $0(0.0)$ \\
\hline Ateş & $116(38.4)$ & $17(39.5)$ & $74(40.8)$ & $25(32)$ \\
\hline Öksürük & $168(55.6)$ & $13(30.2)$ & $97(53.5)$ & $58(74.3)$ \\
\hline Nefes darlığı & $139(46)$ & $8(18.6)$ & $67(31)$ & $64(82)$ \\
\hline Kas ağrısı & $105(34.8)$ & $15(34.8)$ & $70(38.6)$ & $20(25.6)$ \\
\hline Baş ağrısı & $30(9.9)$ & $4(9.3)$ & $19(10.4)$ & $7(9)$ \\
\hline Baş dönmesi & $10(3.3)$ & $1(2.3)$ & $5(2.7)$ & $4(5.1)$ \\
\hline Burun akıntısı & $6(2)$ & $2(4.6)$ & $4(2.2)$ & $0(0)$ \\
\hline Boğaz ağrısı & $38(12.6)$ & $9(20.9)$ & $19(10.4)$ & $10(12.8)$ \\
\hline Balgam & $37(12.3)$ & $2(4.6)$ & $22(12.1)$ & $13(16.7)$ \\
\hline Yatış süre Ort \pm Ss & $10.06 \pm 6.07$ & $6.63 \pm 3.10$ & $8.59 \pm 4.05$ & $15.33 \pm 7.77$ \\
\hline Min-Maks (Medyan) & $2-41(8)$ & $2-14(6)$ & $3-30(8)$ & $4-41(15)$ \\
\hline YBÜ'de yatış & $38(12.6)$ & $0(0)$ & $1(0.6)$ & $37(47.4)$ \\
\hline Ölüm & $15(5)$ & $0(0)$ & $0(0)$ & $15(19.2)$ \\
\hline
\end{tabular}

Hastaların \%88.7'inde $(\mathrm{n}=260)$ toraks BT'sinde tutulum saptand, \%95.8'inde ( $\mathrm{n}=249)$ buzlu cam, \%41.9'unda ( $\mathrm{n}=109)$ infiltrasyon, \%37.7'sinde $(\mathrm{n}=98)$ konsolidasyon izlendi. Hastaların \%90.4'ünde $(\mathrm{n}=235)$ tutulum bilateraldi. Hastaların \%38.8'inde ( $\mathrm{n}=101)$ tüm akciğer alanlarında, \%31.9'unda ( $\mathrm{n}=83$ ) alt loblarda tutulum görüldü. Hastaların Toraks BT bulguları Tablo 3'te verilmiștir. Hastalarda sağllk bakanlığı rehberleri doğrultusunda kullanılan ilaçlar favipiravir \%59.6 ( $\mathrm{n}=180)$, \%13.2'sinde $(\mathrm{n}=40)$ hidroksiklorokin, \%13.6 ( $\mathrm{n}=41)$ favipiravir ve hidroksiklorokin kombinasyonu idi. Hastaların tedavileri ile ilgili özellikler Tablo 4'te verilmiștir. Hastaların hastanede yatıs süreleri ortalama $10.06 \pm 6.07$ (medyan 8) (2-41) gündür, yoğun bakım ünitesinde izlenme oranı \%12.6 olup, hastaların \%5'inde ölüm gerçekleșmiștir.

Hastaların klinik tiplerine göre yapılan karșılaștırmalarda klinik tipi komplike olmayan olguların yașları, hafif-orta pnömoni ve ciddi pnömoni olan olgulara göre anlamlı düzeyde düsük saptanmıstır $(p=0.001 ; p=0.001 ; p<0.01)$. Aynı sekilde klinik tipi hafif-orta pnömoni olan olguların yașları, ciddi pnömoni olan olgulara göre anlamlı düzeyde düșük saptanmıștır $(p=0.001 ; p<0.01)$. Diyabet, hipertansiyon, serebrovaskuler hastalık, komorbidite sayısı 2 ve üzerinde olması, PCR pozitifliği, iștahsızlık, tat kaybı, bulantı-kusma, ishal, öksürük ve nefes darlığı olan olguların klinik tipinin ciddi 
Tablo 2. COVID-19 tanılı hastalarımızın laboratuvar değerleri

\begin{tabular}{|c|c|c|c|c|}
\hline $\mathrm{n}=302$ & $\begin{array}{c}\text { Tüm hastalar Ort } \pm \text { Ss } \\
\text { (Medyan) }\end{array}$ & $\begin{array}{l}\text { Komplike olmayan Ort } \pm \\
\text { Ss (Medyan) }\end{array}$ & $\begin{array}{c}\text { Hafif orta pnömoni Ort } \pm \\
\text { Ss (Medyan) }\end{array}$ & $\begin{array}{l}\text { Ciddi pnömoni Ort } \pm \text { Ss } \\
\text { (Medyan) }\end{array}$ \\
\hline Beyaz küre & $7162.5 \pm 3548.65(6225)$ & $6835.12 \pm 3334.135950)$ & $7103.34 \pm 3686.62(6150)$ & $7480.26 \pm 3349.81(7000)$ \\
\hline Trombositopeni & $35(11.6)$ & $7(16.3)$ & $20(11.0)$ & $8(10.3)$ \\
\hline Lenfosit & $1378.31 \pm 842.74(1230)$ & $1783.95 \pm 795.47(1580)$ & $1426.19 \pm 866.07(1260)$ & $1043.59 \pm 683.32(930)$ \\
\hline$<800$ & $68(22.5)$ & $2(4.7)$ & $33(18.2)$ & $30(38.5)$ \\
\hline$\geq 800$ & $234(77.5)$ & $41(95.3)$ & $148(81.8)$ & $48(61.5)$ \\
\hline PLT & $217.68 \pm 93.84(196.5)$ & $195.49 \pm 56.42(178)$ & $223.55 \pm 99.85(197)$ & $216.31 \pm 95(197)$ \\
\hline Hemoglobin & $13.18 \pm 1.98(13.4)$ & $14.18 \pm 1.83(14.2)$ & $13.18 \pm 1.95(13.4)$ & $12.64 \pm 1.92(12.9)$ \\
\hline CRP & $71.07 \pm 83.47(44.9)$ & $37.66 \pm 58.45(11)$ & $62.21 \pm 72.16(42)$ & $110.44 \pm 104.26(85)$ \\
\hline D vitamin & $13.51 \pm 9.02(11)$ & $12.96 \pm 10.89(10)$ & $13.66 \pm 8.92(11)$ & $13.44 \pm 8.48(12)$ \\
\hline Fibrinojen & $484.91 \pm 142.28(476)$ & $391.95 \pm 117.41(353.5)$ & $488.27 \pm 124.58(479.5)$ & $529.07 \pm 169.23(500)$ \\
\hline D dimer & $1278.34 \pm 1213.49(814)$ & $590.12 \pm 557.91(403)$ & $1173.97 \pm 1116.15(747)$ & $1898.17 \pm 1414.53(1413)$ \\
\hline$<1000$ & $174(56.6)$ & $36(87.8)$ & $111(61.3)$ & $27(35.5)$ \\
\hline$\geq 1000$ & $124(43.4)$ & $5(12.2)$ & $70(38.7)$ & $49(64.5)$ \\
\hline AST & $38.22 \pm 32.16(29.5)$ & $28.74 \pm 16.11(25)$ & $36.36 \pm 26.72(29)$ & $47.74 \pm 45.65(36.5)$ \\
\hline ALT & $31.11 \pm 29.22(23.5)$ & $32.07 \pm 35.55(21.5)$ & $28.9 \pm 23.72(23)$ & $35.71 \pm 36.07(25)$ \\
\hline CK & $117.35 \pm 161.28(69.5)$ & $102.95 \pm 67.63(99)$ & $105.3 \pm 151.73(60)$ & $143.48 \pm 194.98(89.5)$ \\
\hline CKMB & $16.78 \pm 22.24(13)$ & $13.11 \pm 7.88(13)$ & $17.5 \pm 26.64(12)$ & $16.76 \pm 16.16(14)$ \\
\hline Total protein & $8.41 \pm 32.3(6.4)$ & $6.7 \pm 0.57(6.7)$ & $6.43 \pm 0.67(6.5)$ & $13.59 \pm 61.96(6.1)$ \\
\hline Trigliserid & $150.5 \pm 84.18(133.5)$ & $149 \pm 76.64(140)$ & $146.51 \pm 90.97(122.5)$ & $161.4 \pm 69.32(152)$ \\
\hline LDH & $288.63 \pm 114.51(261.5)$ & $202.88 \pm 47.85$ (199) & $277.41 \pm 98.71(251)$ & $359.12 \pm 134.86(332)$ \\
\hline Ferritin & $299.33 \pm 356.59(173)$ & $112.73 \pm 95.63(73.5)$ & $282.37 \pm 344.87(154)$ & $436.61 \pm 415.5(309)$ \\
\hline PCT & $13.02 \pm 89.69(0.2)$ & $19.3 \pm 41.22(0.2)$ & $2.32 \pm 12.34(0.1)$ & $7.50 \pm 23.55(0.4)$ \\
\hline Troponin & $15.78 \pm 40.88(6)$ & $3.81 \pm 2.7(2.7)$ & $12.97 \pm 28.94(5.6)$ & $28.48 \pm 65.32(11.7)$ \\
\hline PTZ & $11.82 \pm 2.23(11.4)$ & $11.83 \pm 2.74(11.3)$ & $11.49 \pm 1.03(11.3)$ & $12.56 \pm 3.46(11.9)$ \\
\hline INR & $1.03 \pm 0.22(1)$ & $1.00 \pm 0.23(1)$ & $1.00 \pm 0.11(1)$ & $1.1 \pm 0.36(1)$ \\
\hline APTT & $24.12 \pm 3.95(23.7)$ & $24.16 \pm 2.96(23.9)$ & $23.94 \pm 3.7(23.4)$ & $24.55 \pm 4.9(24)$ \\
\hline
\end{tabular}

pnömoni olması oranı, diğer gruplara göre anlamlı düzeyde yüksek saptanmıștır $(p<0.05)$. Klinik tipi ciddi pnömoni olan olguların yatıs süresi, komplike olmayan ve hafif-orta pnömoni olanlara göre anlamlı düzeyde yüksek saptanmıștır $(p<$ 0.05). YBÜ'ye yatan hastaların klinik tipinin ciddi pnömoni olması oranı, YBÜ'ye yatmayan hastalara göre anlamlı düzeyde yüksek saptanmıștır $(p<0.05)$. Ölüm durumuna göre hastaların klinik tiplerinin dağılımları arasında istatistiksel olarak anlamlı farklılık saptanmıstır $(p<0.05)$. Ölen hastaların klinik tipinin ciddi pnömoni olması oranı, ölüm gelișmeyen hastalara göre anlamlı düzeyde yüksek saptanmıștır (Tablo 1).

Hastaların klinik tiplerine göre yapılan karș1laștırmalarda klinik tipi ciddi pnömoni olan olgu- ların lenfosit sayısı, hemoglobin, ve total protein komplike olmayan ve hafif orta pnömoni olan olgulara göre anlamlı düzeyde düsük saptanmıștır $(\mathrm{p}<$ 0.05). CRP, fibrinojen, D-dimer, AST, LDH, ferritin, prokalsitonin, troponin, PTZ, INR değeri komplike olmayan ve hafif orta pnömoni olan olgulara göre anlamlı düzeyde yüksek saptanmıștır $(\mathrm{p}<0.05)$ (Tablo 2).

Toraks tomografi sonucuna göre olguların klinik tiplerinin dağılımları arasında istatistiksel olarak anlamlı farklilık saptanmıstır $(p=0.001 ; p<$ 0.01). Toraks tomografisinde infiltrasyon, konsolidasyon, atelektazi, plevral effüzyon varlığı, bilateral tutulum olan ve tüm lobların tutulduğu hastaların klinik tipinin ciddi pnömoni olması oranı anlaml düzeyde yüksek saptanmıștır $(p<0.05)$ (Tablo 3). 
Tablo 3. COVID-19 tanılı hastalarımızın toraks tomografi bulguları

\begin{tabular}{lcccc}
$\mathbf{n = 3 0 2}$ & $\begin{array}{c}\text { Toplam (302) } \\
\mathbf{n}(\%)\end{array}$ & $\begin{array}{c}\text { Komplike olmayan } \\
(\mathbf{4 3 )} \mathbf{n}(\%)\end{array}$ & $\begin{array}{c}\text { Hafif-orta pnömoni } \\
(\mathbf{1 8 1}) \mathbf{n}(\%)\end{array}$ & $\begin{array}{c}\text { Ciddi pnömoni } \\
\mathbf{( 7 8 )} \mathbf{n}(\%)\end{array}$ \\
\hline Toraks BT bulgu var & $260(88.7)$ & $6(14)$ & $176(97.2)$ & $78(100.0)$ \\
Buzlu cam & $249(95.8)$ & $5(11.6)$ & $169(93.3)$ & $75(96.1)$ \\
Infiltrasyon & $109(41.9)$ & $1(2)$ & $64(35.3)$ & $44(56.4)$ \\
Konsolidasyon & $98(37.8)$ & $1(2)$ & $58(32)$ & $39(50)$ \\
Atelektazi & $36(13.8)$ & $2(4.6)$ & $13(7.1)$ & $21(27)$ \\
Plevral effüzyon & $36(12.3)$ & $1(2)$ & $13(7.1)$ & $18(23)$ \\
Bilateral tutulum & $235(90.4)$ & $1(2)$ & $158(87.2)$ & $76(97.4)$ \\
Etkilenen akciğer lobu & & & & \\
Alt lob & $83(31.9)$ & $2(33.3)$ & $74(42)$ & $7(9)$ \\
Üst lob & $10(3.8)$ & $0(0.0)$ & $9(5.1)$ & $1(1.2)$ \\
Tüm loblar & $101(38.8)$ & $2(33.3)$ & $46(26.2)$ & $53(68)$ \\
Üst ve alt loblar & $22(8.5)$ & $0(0.0)$ & $16(9.1)$ & $6(7.7)$ \\
Orta ve alt loblar & $44(16.9)$ & $2(33.3)$ & $31(17.6)$ & $11(14.1)$
\end{tabular}

\section{Tablo 4. COVID-19 tanılı hastalarımızın tedavi özellikleri}

$\begin{array}{lc}\text { Antiviral tedavi } & \mathbf{n}(\%) \\ \quad \text { Favipravir } & 180(59.6) \\ \text { Favipravir+hidroksiklorokin } & 41(13.6) \\ \text { Hidroksiklorokin } & 40(13.2) \\ \text { Hidroksiklorokin+oseltamivir } & 31(10.3) \\ \text { Lopinavir/ritonavir } & 8(2.6) \\ \quad \text { Lopinavir/ritonavir+hidroksiklorokin } & 1(0.3) \\ \quad \text { Favipravir+hidroksiklorokin+oseltamivir } & 1(0.3) \\ \text { Favipravir kullanım günü (Ort } \pm \text { Ss) (Medyan) } & 8 \pm 2.4(10) \\ \text { Hidroksiklorokin kullanım günü (Ort } \pm \text { Ss) (Medyan) } & 5.29 \pm 1.58(5) \\ \text { Oseltamivir kullanım günü (Ort } \pm \text { Ss) (Medyan) } & 4.77 \pm 0.94(5) \\ \text { DMAH kullanımı n (\%) } & 257(85.1) \\ \text { Antibiyotik kullanımı n (\%) } & 219(72.5) \\ \text { Kullanılan antibiyotik } & \mathbf{n}(\%) \\ \quad \text { Moksifloksasin } & 87(40.1) \\ \text { Seftriakson } & 54(24.8) \\ \text { Piperasilin-tazobaktam } & 28(12.9) \\ \text { Azitromisin } & 26(12) \\ \text { Meropenem } & 22(10.1) \\ \text { Steroid kullanımı } n(\%) & 83(27.5)\end{array}$

\section{TARTIȘMA}

Ciddi hastalığı olan COVID-19 hastalarının yas ortalaması ciddi olmayan hastalara göre daha yüksektir $^{[4]}$. Zhang ve arkadașlarının çalıșmasında da 60 yas üzerinde hastaların ciddi hastalık oranı 60 yas altına göre anlamlı olarak yüksek bulunmuştur ${ }^{[8]}$. Zhou ve arkadașlarının calıșmasında ciddi hastaların yas ortalaması 50.5, ciddi olmayan hastaların ise 42 olup, aradaki fark anlamlı olarak bildirilmiștir $^{[9]}$. Ülkemizden benzer çalıșmalar de- 
ğerlendirildiğinde ciddi hastalığı olan hastaların yas ortalamaları ciddi olmayan hastalara göre daha yüksek bulunmuștur ${ }^{[10,11]}$. Calıșmamızda hastalarımızın \%51.3'ü 65 yaș üzerindedir ve ciddi hastalığı olan hastaların yas ortalamasının ciddi olmayan hastalara göre anlamlı derecede yüksek olduğu görülmüștür. Calıșmamıza dahil edilen hastaların \%50.3'ünü erkek cinsiyet olușturmaktadır. Klinik tiplere göre karșılaștırıldığında ciddi hastalığı olan ve ciddi olmayan hastalığı olanlar arasında cinsiyet yönünden farklılık saptanmamıștır. Benzer olarak yapilan çalıșmalarda ciddi hastalığı olan hastalar ile ciddi hastalığı olmayan gruplar arasında cinsiyet yönünden farklılık bildirilmemiş$\operatorname{tir}^{[8,9,11]}$.

Calıșmamizda en sik saptanan altta yatan hastalıklar literatürle de uyumlu olarak diyabetes mellitus, hipertansiyon, kronik obstrüktif akciğer hastalığı ve kardiyovasküler hastalıklardır ${ }^{[1,10,11]}$. Calıșmamızda komorbidite sayısı 2 ve üzeri olan hasta grubunda ciddi hastalık olma oranı daha yüksektir. Calıșmamızla uyumlu olarak yaplan çalıșmalarda komorbid hastalık sayısı ciddi hastalığı olanlarda anlamlı olarak daha fazla bildirilmiștir ${ }^{[4,9-11]}$. Calıșmamızda en sık saptanan sikayetler sırasıyla halsizlik, öksürük, nefes darlığı, iștahsızlık, ates ve kas ağrısı olup literatürle uyumludur ${ }^{[1,4,10-13]}$. Calıșmamızda öksürük, nefes darlığı, ishal, bulantı-kusma, iștahsızlık ve tat kaybı olan hastalarda ciddi hastalık oranı anlamlı olarak daha yüksektir. Gastrointestinal sikayetleri olan grupta hastalığın ciddi seyretmesi, hastalıkla ilișkilendirilen ön planda olmayan sikayetlere de dikkat cekmesi bakımından önemlidir.

Çalıșmamızda ciddi hastalığı olan hastalarda laboratuvar değerleri değerlendirildiğinde lenfosit sayısı, fibrinojen, total protein ciddi olmayan hastalara göre daha düșük, CRP, D-dimer, AST, LDH, prokalsitonin, ferritin, troponin, INR, PTZ değerleri ciddi olmayan hastalara göre daha yüksek saptanmıștır. Yapılan bir calıșmada lenfosit sayısında düșüklük, CRP, D-dimer, ferritin, prokalsitonin değerlerinde yükseklik ciddi hastalığ1 olan hastalarda anlamlı olarak daha fazla bulunmuștur ${ }^{[11]}$. Calıșmamızla uyumlu olarak yapilan çalıșmalarda ciddi hastalığı olanlarda lenfopeni, trombositopeni, total protein düșüklüğü, hipoalbunemi, CRP, AST, ALT, D-dimer, ve prokalsitonin değerlerinde anlamlı olarak yükseklik saptanmıștir ${ }^{[4,8,14-17]}$.

Hastalarımızda toraks BT'de COVID-19'la uyumlu bulgu saptanma oranı \%88.7 olup en s1k gözlenen bulgu buzlu cam görünümüdür, \%90'ında tutulum bilateraldir ve en sik tüm loblar etkilenmiștir. Benzer olarak yapılan bir calıșmada toraks BT'de COVID-19'la uyumlu bulgu saptanma oranı \%93.3 olup \%86'sinda bilateral tutulum saptanmiștır. En sık saptanan buzlu cam görünümü ve konsolidasyondur $^{[4]}$. Ülkemizden yapilan bir çalıșmada bilateral tutulumun \%73 oranında görüldüğü ve en sık tüm akciğer lobları, sonrasında da alt akciğer loblarında tutulum olduğu bildirilmiștir ${ }^{[10]}$. Calıșmamızda toraks BT'de saptanan bulgular ve tutulum paterni literatürle uyumludur ${ }^{[4,10,14]}$. COVID-19 tanısında yardımcı testlerden biri de yüksek duyarlılığı nedeniyle toraks BT'dir ${ }^{[18]}$. Yapılan bir diğer çalıșmada ise buzlu cam görünümünün ciddi hastalarda daha fazla olduğu, multilober tutulum, konsolidasyon ve infiltrasyonun ciddi hastalığı olanlarda anlamlı olarak daha fazla olduğu bildirilmiștir ${ }^{[11]}$. Hastalarımızda toraks BT'de konsolidasyon, infiltrasyon, atelektazi, plevral effüzyonu olanlarda, akciğerlerin bilateral tutulumunda yine tüm lobların etkilendiği hastalarda ciddi hastalık olma oranı ciddi olmayan hastalara göre anlaml olarak yüksek saptanmıștır.

Bugün için COVID-19 tedavisinde etkinliği kanıtlanmıș kesin bir ilaç tedavisi bulunmamaktadır. Ülkemizde Sağlık Bakanlığı'nın COVID-19 tedavi rehberi önerileri doğrultusunda hastalarımıza salgının ilk dönemlerinde hidroksiklorokin tedavisi bașlanmıștır, ancak yapilan cok sayıda geniș randomize calıșmanın ardından hastalarda klinik bir yararı ve mortaliteyi azaltmada bir katkısı olmadığı sonucuna varılmıs, rehber önerilerinden çkarılmıstır $^{[19]}$. Favipiravir bir RNA polimeraz inhibitörü olup daha önce bazı Asya ülkelerinde influenza tedavisinde kullanılmıștır. Rusya ve Cin'den bildirilen calıșmalarda yararı gösterilmiș, İran'dan yapılan bir calıșmada ise ciddi hastalarda yararı olmadığı bildirilmiștir ${ }^{[20-22]}$. Calıșmamızda tedavide hastalarımızın \%59.6'sında favipiravir, \%13.2'sinde hidroksiklorokin, \%13.6'sında favipiravir ve hidroksiklorokin kombine kullanılmıștır.

Hastalarımızın \%5'inde ölüm gercekleșmistir, ölüm gelișen hastaların hepsi YBÜ'sinde izlenen 
hastalardır. COVID-19 nedeniyle YBÜ'ye kabul oranlarındaki farklllıklar bulunmaktadır, bu durum YBÜ'nün uygulama ve kabul kriterlerindeki yerel, kültürel ve coğrafi farklllıklar ile YBÜ'nin hizmet verdiği bölgedeki nüfus özelliklerindeki farklılıklarla ilgili olabilir. Örneğin, Çin'den gelen kohortlar arasinda, hastanede yatan hastalarda YBÜ'ye kabul oranları \%7 ile 26 arasında değișmektedir. Benzer sekilde, İtalya'da YBÜ'ye yatıșların oranı \%5 ila 12 arasinda olup ve hastanede yatan tüm hastaların \%16'sını olușturmaktadır. ABD ve Kanada'da YBÜ'ne kabul oranları \%5 ile 81 arasında değișmektedir ${ }^{[23]}$. Calıșmamızda hastalarımızın \%12.6's hastalığın progresyonu nedeniyle YBÜ'ye devir olmuștur. Ciddi hastalığı olan hastalarımızda hastanede yatıs süresi, YBÜ'de izlenme ve ölüm oranı anlamlı olarak daha yüksektir. Mevcut bulgularımız literatuir ile uyumludur $[9,11,14]$.

Sonuc olarak; çalıșmamızda COVID-19 tanıs1 olan ve hastanede yatarak izlenen hastalar değerlendirilmiș ve hastalık ciddiyetini belirleyen faktörler belirlenmeye calıșılmıștır. Ciddi hastalığı olan COVID-19 hastalarımızda hastanede yatıs süresi, YBÜ'de yatıș ve ölüm oranı anlamlı derecede yüksektir. $\mathrm{Bu}$ nedenle ciddi COVID-19 icin demografik, klinik ve laboratuvar prognostik faktörlerin tanımlanması önem tașımaktadır. Calıșmamızdan elde edilecek verilerin COVID-19 hastalarının takip ve tedavisinde hekimlere katkı sağlayabileceğini düșünmekteyiz.

\section{ETIK KURUL ONAYI}

Çalıșma için, Kütahya Sağlık Bilimleri Üniversitesi Rektörlüğü Girișimsel Olmayan Klinik Araștırmalar Etik Kurulu'ndan onay alındı (Tarih: 09.02.2021, Karar No: 2020/02-21).

\section{ÇIKAR ÇATIȘMASI}

Yazarlar bu makale ile ilgili herhangi bir çkar catıșması bildirmemișlerdir.

\section{YAZAR KATKISI}

Anafikir/Planlama: Tüm yazarlar

Analiz/Yorum: DMÖ, PK

Veri sağlama: Tüm yazarlar

Yazım: DMÖ, PK

Gözden Geçirme ve Düzeltme: Tüm yazarlar

Onaylama: Tüm yazarlar

\section{KAYNAKLAR}

1. Chen T, Wu D, Chen H, Yan W, Yang D, Chen G, et al. Clinical characteristics of 113 deceased patients with coronavirus disease 2019: retrospective study. BMJ 2020;368:m1091.

2. Sümer ş, Ural O, Aktuğ-Demir $N$, Çiftçi ş, Türkseven $B$, Kılınçer $A$, et al. Clinical and laboratory characteristics of COVID-19 cases followed in Selçuk University Faculty of Medicine. Klimik Derg 2020;33:122-7.

3. Zhang H, Shang W, Liu Q, Zhang X, Zheng M, Yue M. Clinical characteristics of 194 cases of COVID-19 in Huanggang and Taian, China. Infection 2020;48:687-94.

4. Zhan T, Liu M, Tang Y, Han Z, Cheng X, Deng J, et al. Retrospective analysis of clinical characteristics of 405 patients with COVID-19.J Int Med Res 2020;48:300060520949039.

5. T.C Sağılk Bakanlığı COVID-19 Bilimsel Danışma Kurulu Çalışması: Genel bilgiler, epidemiyoloji, tanı. Erişim tarihi 15 Temmuz 2021. Available from: https://COVID19.saglik. gov.tr/Eklenti/39551/0/COVID-19rehberigenelbilgilerepidemiyolojivetanipdf.pdf

6. Alsofayan YM, Althunayyan SM, Khan AA, Hakawi AM, Assiri AM. Clinical characteristics of COVID-19 in Saudi Arabia: A national retrospective study. I Infect Public Health 2020;13:920-5.

7. T.C. Sağıı Bakanlığı COVID-19 Bilimsel Danışma Kurulu Çalışması:Erişkin hasta tedavisi. Erişim tarihi 15 Temmuz 2021. Available from: https://COVID19.saglik.gov.tr/Eklenti/39061/0/COVID-19rehberieriskinhastatedavisipdf.pdf

8. Zhang G, Zhang J, Wang B, Zhu X, Wang Q, Qiu S. Analysis of clinical characteristics and laboratory findings of 95 cases of 2019 novel coronavirus pneumonia in Wuhan, China: a retrospective analysis. Respir Res 2020;21:74.

9. Zhao $X Y, X U X X$, Yin $H S$, Hu QM, Xiong $T$, Tang $Y Y$, et al. Clinical characteristics of patients with 2019 coronavirus disease in a non-Wuhan area of Hubei Province, China: a retrospective study. BMC Infect Dis 2020;20:311.

10. Karakoç ZÇ, Pınarbaşı-Şimşek B, Asil R, Dodurgalı R, Çalışkaner F, Özsarı $A$, et al. First wave in COVID-19 pandemic: A single center experience. Klimik Derg 2020;33:223-9.

11. Ersan G, Akkiraz Baç G, Yüksel Ö, Yıldız FŞ, Papila Ç, Arsu $G$, et al. The Demographic and Clinical Features of 479 COVID-19 Patients: A Single-center Experience. Mediterr J Infect Microb Antimicrob 2020;9:9.

12. Liu K, Fang YY, Deng Y, Liu W, Wang MF, Ma JP, et al. Clinical characteristics of novel coronavirus cases in tertiary hospitals in Hubei Province. Chin Med I (Engl) 2020;133(5):1025-31.

13. Wang D, Hu B, Hu C, Zhu F, Liu X, Zhang J, et al. Clinical Characteristics of 138 Hospitalized Patients With 2019 Novel Coronavirus-Infected Pneumonia in Wuhan, China. JAMA 2020;323:1061-9.

14. Ture Z, Kalin-Unüvar G, Baran Ketencioğlu B, Zararsız G, Tok T, Temel Ş, et al. Analysis of Factors Associated with Disease Outcomes in Hospitalized Patients with COVID-19, Experience of a Single Center in Turkey. Infect Dis Clin Microbiol 2020;2:61-70. 
15. Ou M, Zhu J, Ji P, Li H, Zhong Z, Li B, et al. Risk factors of severe cases with COVID-19: a meta-analysis. Epidemiol Infect 2020;148:e175.

16. Guan WJ, Ni ZY, Hu Y, Liang WH, Ou CQ, He JX, et al. Clinical characteristics of 2019 novel coronavirus infection in China. The New Eng J Med 2020;382:1708-20.

17. Filiz M, Yılmaz G, Fidan G, Köşger S, Kadıoğlu E, Savaşçı Ü ve ark. COVID-19 pandemisinde üçüncü basamak bir hastane deneyimi. FLORA 2021;26:257-66.

18. Ojha V, Mani A, Pandey NN, Sharma S, Kumar S. CT in coronavirus disease 2019 (COVID-19): a systematic review of chest CT findings in 4410 adult patients. Eur Radiol 2020;30:6129-38.

19. Kim YA. COVID-19: Management in hospitalized adults. Erişim tarihi:15 Temmuz 2021. Available from: https://www. uptodate.com/contents/COVID-19-management-in-hospitalized-adults? search=COV\%C4\%BOD\%2019\%20TREATMENT\&source=search_result\&selectedTitle =1 150\&usage_type=default\&display_rank=1

20. Ivashchenko AA, Dmitriev KA, Vostokova NV, Azarova VN, Blinow AA, Egorova AN, et al. AVIFAVIR for Treatment of Patients with Moderate COVID-19: Interim Results of a Phase II/III Multicenter Randomized Clinical Trial. Clin Infect Dis 2020:ciaa1176.
21. Cai Q, Yang M, Liu D, Chen J, Shu D, Xia J, et al. Experimental Treatment with Favipiravir for COVID-19: An Open-Label Control Study. Engineering (Beijing) 2020;6:1 192-8.

22. Solaymani-Dodaran $M$, Ghanei $M$, Bagheri $M$, Qazvini A, Vahedi $E$, Hassan Saadat $S$, et al. Int Immunopharmacol 2021;95:107522.

23. Anesi LG. COVID-19: Epidemiology, clinical features, and prognosis of the critically ill adult. Erişim tarihi: 15 Temmuz 2021. Available from: https://www.uptodate.com/contents/COVID-19-epidemiology-clinical-features-and-prognosis-of-the-critically-ill-adult?sectionName =Rate\%20 and\%20risk\%20of\%20progression\%20to\%20critical\%20 illness\&topicRef=128323 \&anchor $=$ H2091959514\&source=see_link\#H2091959514)

\section{Yazıșma Adresi/Address for Correspondence} Dr. Pinar KORKMAZ

Kütahya Sağlık Bilimleri Üniversitesi Tıp Fakültesi, İnfeksiyon Hastalıkları Anabilim Dalı, Kütahya-Türkiye

E-posta: drpinarkor@gmail.com 